\title{
FORECASTING PRODUCTION EFFECTS OF IRRIGATED FABA BEAN (VICIA FABA VAR. MINOR) DEPENDING ON DROUGHT LEVELS
}

\author{
Stanisław Dudek, Renata Kuśmierek-Tomaszewska, Jacek Żarski \\ UTP University of Science and Technology in Bydgoszcz, Poland \\ zarski@utp.edu.pl
}

\begin{abstract}
The aim of the article was to develop formulas, which can be used to model forecasts of production and economic effects of irrigated faba bean (Vicia faba var. minor), depending on drought severity level in a growing season. For the analysis we used data of ten-year $(2005$ - 2014) production effects of irrigated faba bean and indices calculated on the basis of meteorological data from the measuring point set in the vicinity of the experimental site in region of Bydgoszcz city, central Poland. Based on them, the most relevant relationships between irrigation productivity and chosen drought indices, calculated for a period of high water needs of the plant, were searched. Presented results have demonstrated that the non-irrigated faba bean yields depended significantly on drought severity level and showed very high variability in time. Irrigation contributed to a significant $49 \%$ increase in yields and their stability in the years. Due to this treatment, the coefficient of variation of the yield decreased from 55.1 to $19.6 \%$. The production effects of irrigation depended significantly on moisture conditions over the period of high water needs of faba bean. In wet seasons, the increases in yields due to irrigation were insignificant and about three-fold lower, while in the dry periods - more than a half higher $(57 \%)$ than the average increases. The results presented in the work are of great importance because they can be used to model forecasts of production, as well as to plan the development of irrigation systems in the given area.
\end{abstract}

Key words: drip irrigation, faba bean, yield, drought index, atmospheric precipitation, evapotranspiration.

\section{Introduction}

Faba bean is a leguminous plant whose seeds are widely used as a component for blends with other livestock feeds. An important feature of faba bean is a high protein content of $25-30 \%$, the ability to bind atmospheric nitrogen in the process of symbiosis with Rhizobia. This plant has also a structure-creating effect by enriching the soil with organic matter and nutrients, and improving its physical and chemical properties (Podleśny, 2005). All this causes faba bean to be a desirable forecrop for cereals, especially for winter wheat (Triticum aestivum), which is dominant in the structure of sowings. Despite these advantages, the area of cultivation of legumes in Poland, including faba bean, in the first decade of the 21 st century was only about 100 thousand hectares (Podleśny, 2005) and only after receiving special subsidies under the EU Common Agricultural Policy it exceeded 400 thousand hectares in 2015 (Adamska et al., 2016). The ecological importance of this plant, confirmed by many EU research programs (Święcicki, Chudy, \& Żuk-Gołaszewska, 2007), indicates that this trend will be perpetuated.

The main disadvantage of all legumes, including faba bean representing the coastal climate plants, is lower yielding in dry growing seasons, when atmospheric precipitation totals are considerably reduced. In the transitional climate in central part of Poland, atmospheric droughts that turn into soil droughts, and in some cases even into hydrological ones, are frequent and irregular (Labędzki, 2007). Their severity and range were observed in the last 30 years in the growing seasons of 1989, 1992, 2000, 2003, 2008 and 2015 (Żarski et al., 2017). The occurrence of drought during increased water needs of faba bean, coinciding with the reproductive phase, contributes to the deterioration of yield, not only in terms of quantity, but also quality (Szukała et al., 2007; Dudek, Żarski, \& Kuśmierek-Tomaszewska, 2011; 2013; Di Paolo, Garofalo, \& Rinaldi, 2015; Rokosz \& Podsiadło, 2015).

An effective treatment, applied to prevent the negative effects of drought in plant production, is irrigation. The use of irrigation systems in Poland, despite the rapid development of the country, is still a future solution. However, this creates an alternative for theprogress in agricultural production in the future. Factors that accelerate the development of irrigation in agriculture, apart from providing higher and more stable, good quality yields, include the noticeable progress in modernity of farms and a raise of their competitiveness, as well as the forecasted climate change (Łabędzki, 2009; Rzekanowski, Żarski, \& Rolbiecki, 2011).

The aim of the article was to develop formulas for a model determining production effects of irrigated faba bean, depending on a drought severity, based on meteorological indices representing moisture conditions.

\section{Materials and Methods}

For the analysis we used meteorological data from the agrometeorological monitoring, gained from the measuring point owned by the Department of Land Reclamation and Agrometeorology (UTP University of Science and Technology in Bydgoszcz, Poland) and the yields of irrigated and non-irrigated faba bean. The 
procedures used in the meteorological measurements were compliant with the World Meteorological Organization (Guide to Meteorological Instruments and Methods of Observation, 2014) measuring standards. The experimental site is located in Mochełek village, about $20 \mathrm{~km}$ away from Bydgoszcz city center, on the south-eastern edge of the Krajeńska Upland $\left(53^{\circ} 13^{\prime} \mathrm{N}, 17^{\circ} 51^{\prime} \mathrm{E}, 98.5 \mathrm{~m}\right.$. a. s. 1.); in the zone of the highest average precipitation deficit and high needs for supplementary irrigation in Poland in terms of the climate criterion (Labędzki, 2007; Rzekanowski, Żarski, \& Rolbiecki, 2011; Żarski et al., 2017). The experiment was set up in Luvisol (LV) with a fine sandy loam texture (World reference base for soil resources 2014). In terms of compaction, it is a sandy soil on compact subsoil.

Data obtained from the long-term field experiment of sprinkler irrigated faba bean grown for seeds, carried out in 2005-2014 were used in the study. Considering the soil conditions of the experiment, irrigation was, typically for Poland's climate conditions, used in emergency, supplementing the seasonal precipitation deficit over the period of high water needs of the crop tested. The plants were optimally irrigated, ensuring the reserve of readily available water throughout the period of high water needs, which span the phases from the beginning of flowering $\mathrm{BBCH} 60$ to the technical maturity of seeds $89 \mathrm{BBCH}$, in the soil layer with controlled moisture level, which means that water needs of plants during the growing season were fully covered (the soil moisture was maintained in the range of $\mathrm{pF}$-value of $2.0-2.5$ ). Faba bean was irrigated with a portable system with low-pressure Nelson type sprinklers, withthe unit capacity of 200 $\mathrm{dm}^{3} \mathrm{~h}^{-1}$. The irrigation dates were determined based on information from continuous soil root layer moisture monitoring, by balancing the reserve of readily available water based on the weather parameters and direct soil moisture measurements using Fieldscout TDR 300 Soil Moisture Meter probe. The number of disposable irrigation doses and the total seasonal dose depended on the weather conditions, mainly on the amount and distribution of atmospheric precipitation. Detailed information on the factors, the pattern of experiment, and faba bean agrotechnics can be found in the works of Dudek et al. $(2011,2013)$.

In order to determine the most significant relationships between the production effects of irrigated faba bean in the subsequent years and selected indicators characterizing the moisture content during the period of high water needs of faba bean from 1 June to 31 July, a correlation and regression analysis was applied. The critical value of the correlation coefficient for a number of paired observations $\mathrm{n}=10$ at the significance level $\mathrm{p}=0.05$ is 0.6319 . The following indicators were considered for the analysis: absolute precipitation $(\mathrm{P})$, relative precipitation index (RPI) (Bąk \& Łabędzki, 2002), standardized precipitation index (SPI), described by Guttman (1999), as well as the ratio of precipitation to potential evapotranspiration (ET), calculated on the basis of the Grabarczyk's formula:

$$
E T=0.32\left(d+\frac{1}{3} t\right)
$$

where $d$ - mean vapor pressure deficit in $\mathrm{hPa}, t-$ mean air temperature in ${ }^{\circ} \mathrm{C}$. According to the studies by Grabarczyk \& Żarski (1992), the value of potential evapotranspiration calculated for grass according to the Grabarczyk's formula correlated stronger with real evapotranspiration compared to the ET values calculated on the basis of the Penman's equation. The season of 2010 was excluded from the regression analysis due to the extremely unevenly distributed rainfall. In June and July of 2010, the total rainfall was $125.5 \mathrm{~mm}$, but as much as $100.2 \mathrm{~mm}$ fell only in the last week of July. As a result, the yield of nonsprinkled faba bean was much lower, and the effects of sprinkler irrigation were significantly higher than those determined by regression equations.

\section{Results and Discussion}

In respective years, taken for the analysis, weather conditions in the period of high water needs of faba bean (growth phases BBCH 61-89), varied a lot. The average rainfall total was $140.7 \mathrm{~mm}$, changing from $46.0 \mathrm{~mm}$ in 2006 to as much as $249.4 \mathrm{~mm}$ in 2012 . The RPI ranged from 38 to $203 \%$, SPI from -1.66 to 1.87 , and the level of coverage of evapotranspiration by precipitation - from 0.12 to 1.26 . Three dry, three normal and four wet seasons were recorded. Therefore, in such rainfall conditions, irrigation was applied in emergency cases, which is typical for the climate of central Poland (Rzekanowski, Żarski, \& Rolbiecki, 2011; Żarski et al., 2017) (Table 1).

In central Poland, the irrigation's role is to supplement precipitation deficit, unlike in the dry and semi-dry climate zones, where it is a basic and indispensable yield-forming practice. This treatment is applied mainly in the case of long periods without rain. In the temperate climate of Poland, there occur periods and even whole growing seasons when it is used very rarely or it is not applied at all. In our research, such a situation took place in 2007 (faba bean was irrigated only once) while in 2009, due to evenly distributed rainfall in June and July, application of irrigation was not necessary. National research aiming at the improving irrigation in central Poland cover primarily the aspects of its advisability in various crop cultivations by determining the production and economic efficiency and changes in the quality of yield (Rolbiecki et al., 2000; Dudek et al., 2011; 
Moisture content indicators and the total irrigation rates over the period of high water needs in faba bean from June to July

\begin{tabular}{|l|l|c|c|c|c|c|c|}
\hline \multicolumn{1}{|c|}{ Year } & \multicolumn{1}{|c|}{$\begin{array}{c}\text { Drought level } \\
\text { acc. to SPI }\end{array}$} & $\begin{array}{c}\text { P } \\
\mathrm{mm}\end{array}$ & $\begin{array}{c}\text { RPI } \\
\%\end{array}$ & SPI & $\begin{array}{c}\text { ET } \\
\mathrm{mm}\end{array}$ & P/ET & $\begin{array}{c}\text { D } \\
\mathrm{mm}\end{array}$ \\
\hline 2005 & moderately dry & 64.1 & 52 & -1.11 & 290 & 0.22 & 140 \\
\hline 2006 & very dry & 46.0 & 38 & -1.66 & 372 & 0.12 & 110 \\
\hline 2007 & moderately wet & 210.2 & 171 & 1.42 & 224 & 0.94 & 25 \\
\hline 2008 & mild dry & 74.2 & 61 & -0.85 & 277 & 0.27 & 200 \\
\hline 2009 & wet & 175.4 & 143 & 0.97 & 186 & 0.94 & 0 \\
\hline 2010 & normal & 125.5 & 102 & 0.20 & 268 & 0.47 & 180 \\
\hline 2011 & very wet & 233.3 & 190 & 1.69 & 221 & 1.06 & 65 \\
\hline 2012 & very wet & 249.4 & 203 & 1.87 & 198 & 1.26 & 65 \\
\hline 2013 & normal & 128.3 & 105 & 0.24 & 223 & 0.58 & 120 \\
\hline 2014 & normal & 100.3 & 82 & -0.27 & 211 & 0.48 & 140 \\
\hline Average & normal & 140.7 & 115 & 0.45 & 247 & 0.57 & 104 \\
\hline
\end{tabular}

$\mathrm{P}$ - absolute precipitation, RPI - relative precipitation index, SPI - standardized precipitation index, P/ET - precipitation to potential evapotranspiration ratio, $\mathrm{D}$ - total irrigation rate.

2013; Żarski et al., 2013; Rolbiecki et al., 2015; Wszelaczyńska et al., 2015), as well as optimizing irrigation doses in relation to the water needs of plants (Kuśmierek-Tomaszewska, Żarski, \& Dudek, 2012). In climatic zones where irrigation plays the main role as a factor shaping the yield, the prospects and effects of partial coverage of plant's demand for water are examined, due to the need to save water. In reference to the species Vicia faba L., such research was conducted inter alia by Bryla, Banuelos, \& Mitchell (2003), Di Paolo, Garofalo, \& Rinaldi (2015), Ouji et al. (2017) and S. Sarkar, A. Sarkar, \& Zaman (2017).
The results indicate that the yield of non-irrigated faba bean was, on average, in the research years $3.21 \mathrm{t} \mathrm{ha}^{-1}$ (Table 2). In respective years, the yields showed a very high variation - from 0.58 to $5.55 \mathrm{tha}^{-1}$. The coefficient of variation (CV) for them accounted for $55.1 \%$. The regression analysis (Figure 1) demonstrated that yielding depended significantly on moisture content over the period of high water needs in faba bean growth stages from 60 to 89 according to the BBCH spanning June - July. Of all the indicators analyzed, the strongest correlation with the seed yield in non-irrigated faba bean referred to the P/ET

Table 2

Seed yields and sprinkler irrigation effectiveness in faba bean depending on drought level

\begin{tabular}{|c|c|c|c|c|c|c|c|}
\hline \multirow{2}{*}{ Year } & \multirow{2}{*}{ SPI } & \multirow{2}{*}{$\begin{array}{l}\text { Drought level } \\
\text { acc. to SPI }\end{array}$} & \multicolumn{2}{|c|}{$\begin{array}{c}\text { Seed yield at } 15 \% \text { moisture } \\
\text { content }\left(\mathrm{t} \mathrm{ha}^{-1}\right)\end{array}$} & \multicolumn{3}{|c|}{$\begin{array}{l}\text { Seed yield increase under } \\
\text { irrigation }\end{array}$} \\
\hline & & & $\mathrm{O}$ & $\mathrm{W}$ & $\mathrm{tha}^{-1}$ & $\%$ & $\mathrm{~kg} \cdot \mathrm{mm}^{-1}$ \\
\hline 2005 & -1.11 & moderately dry & 2.05 & 4.23 & 2.18 & 106 & 15.6 \\
\hline 2006 & -1.66 & very dry & 1.44 & 3.52 & 2.08 & 144 & 18.9 \\
\hline 2007 & 1.42 & moderately wet & 4.14 & 5.01 & 0.87 & 21 & 34.8 \\
\hline 2008 & -0.85 & mild dry & 0.58 & 3.70 & 3.12 & 538 & 15.6 \\
\hline 2009 & 0.97 & wet & 5.26 & 5.38 & $0.12 *$ & 2 & 0.0 \\
\hline 2010 & 0.20 & normal & 1.23 & 4.89 & 3.66 & 298 & 20.3 \\
\hline 2011 & 1.69 & very wet & 3.44 & 3.84 & 0.40 & 12 & 6.2 \\
\hline 2012 & 1.87 & very wet & 5.55 & 6.27 & 0.72 & 13 & 11.1 \\
\hline 2013 & 0.24 & normal & 4.58 & 5.88 & 1.30 & 28 & 10.8 \\
\hline 2014 & -0.27 & normal & 3.83 & 5.10 & 1.27 & 33 & 9.1 \\
\hline Average & 0.45 & normal & 3.21 & 4.78 & 1.57 & 49 & 15.0 \\
\hline
\end{tabular}

$\mathrm{O}$ - non-irrigated plants, $\mathrm{W}$ - irrigated plants; *- the difference insignificant at the level of $\mathrm{p}=0.05$. 

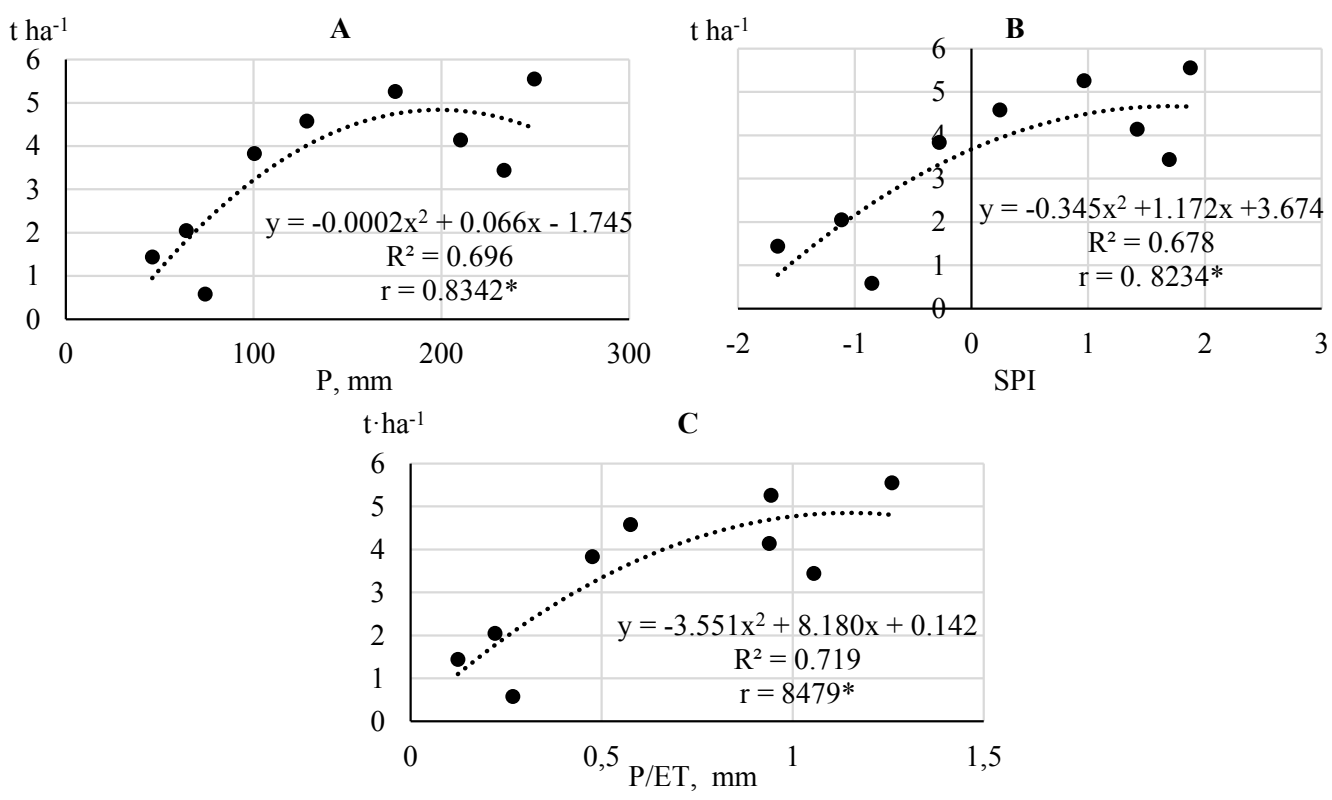

Figure 1. Relationship between the seed yield of faba bean grown without irrigation and moisture conditions over the period of high water needs: A - precipitation, B - standardized precipitation index SPI, $\mathrm{C}$ - precipitation to evapotranspiration ratio.

ratio (Figure 1); however the other indicators, i.e. absolute precipitation and SPI determined the yield to a comparable statistical significance. The polynomial regression equations (Figure 1) show that the optimal precipitation for faba bean in the period from June to July was $190-210 \mathrm{~mm}$, and the $\mathrm{P} / \mathrm{ET}$ ratio $1.10-1.20$.
Seed yields of irrigated plants were on average $4.78 \mathrm{t} \mathrm{ha}^{-1}$, ranging in respective years from 3.52 to $6.27 \mathrm{t} \mathrm{ha}^{-1}$ (Table 2). Irrigation enhanced the yield stability since the coefficient of variation of the seed yield in irrigated faba bean accounted for $19.6 \%$.

Irrigation ensured the adequate plant growth and development, as well as intensified physiological
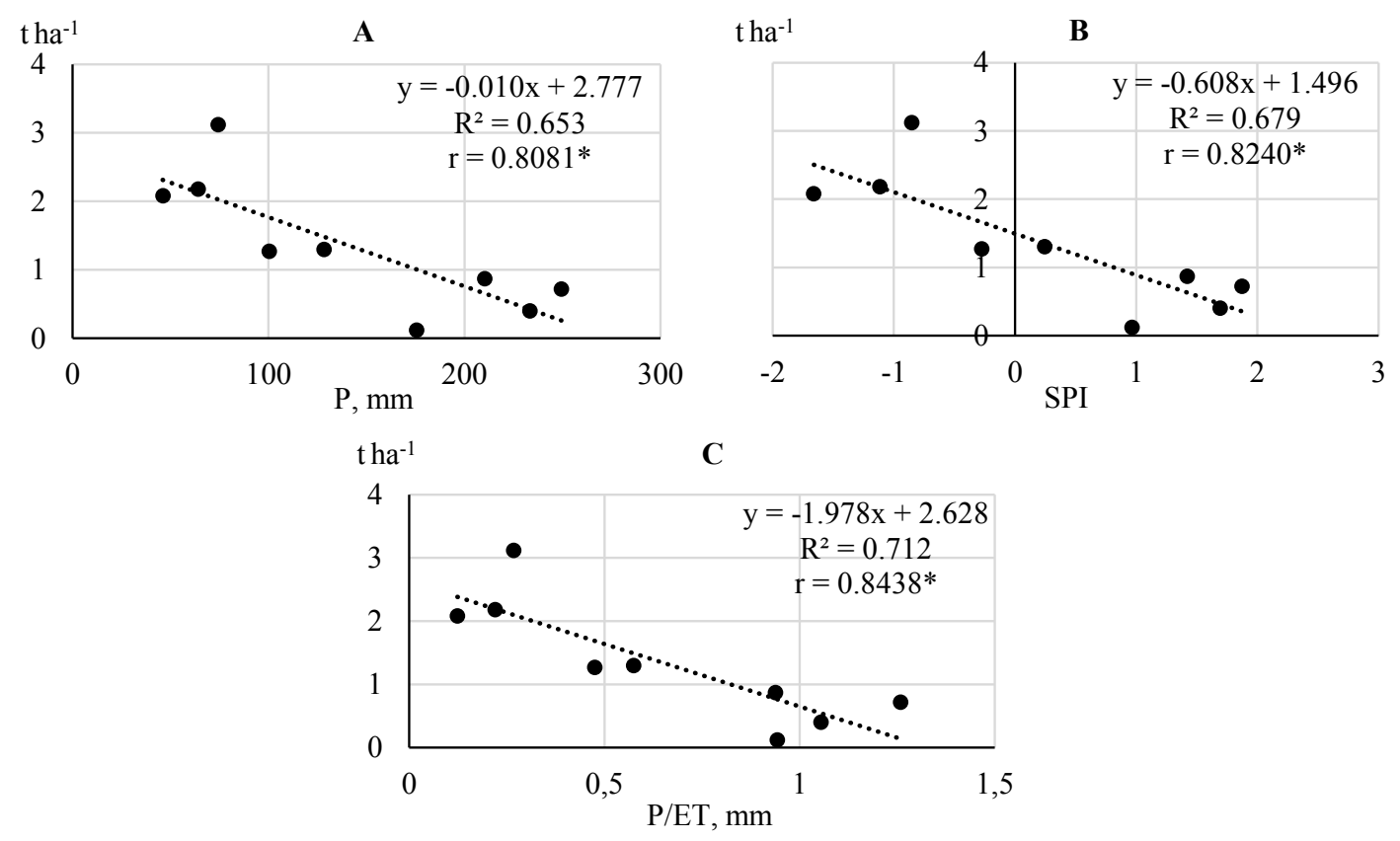

Figure 2. Linear relationship between faba bean seed yield increases due to irrigation and moisture conditions over the period of high water needs: A - precipitation, B - standardized precipitation index SPI, $\mathrm{C}$ - precipitation to evapotranspiration ratio. 
processes. As the result, the average multiannual production effect of irrigated faba bean was $1.57 \mathrm{t} \cdot \mathrm{ha}^{-1}$, which accounted for a $49 \%$ increase in seed yield. One $\mathrm{mm}$ of water used for irrigation caused an average increase in seed yield at the level of $15.0 \mathrm{~kg} \cdot \mathrm{mm}^{-1} \cdot \mathrm{ha}^{-1}$. In particular growing seasons, the irrigation production effects depended significantly and linearly on indices representing moisture conditions during the periods of high water needs of faba bean (Figure 2). The best indicator of those effects was absolute precipitation $\left(\mathrm{R}^{2}=0.712\right)$. The regression equation shows that increases in yields due to sprinkler irrigation are insignificant only when precipitation in June through July exceeds $250 \mathrm{~mm}$ and the P/ET ratio exceeds the value of 1.20.

The average production effects of faba bean irrigation presented in this work point to a great potential of increasing the production of faba bean in central Poland, provided that the water factor is optimized. Therefore, it can be concluded on the basis of the obtained results that the application of irrigation in the production of faba bean is a justified treatment. However, in agricultural practice, making that treatment common will depend to a great extent on the economic conditions, which have an impact on seed prices (Adamska et al., 2016), as well as on infrastructural conditions - mainly the availability of water sources for irrigation purpose (Rzekanowski, Żarski, \& Rolbiecki, 2011; Żarski et al., 2013).

\section{Conclusions}

Presented results, based on the data from multiannual field experiment with sprinkler irrigation in faba bean grown in central Poland have demonstrated that the non-irrigated faba bean yields depended significantly on indicators characterizing moisture conditions. The results demonstrated a very high temporal variation. Irrigation contributed to a significant $49 \%$ increase in yields and their stability over the years. Due to that treatment, the CV of the yield decreased from 55.1 to $19.6 \%$. The production effects of irrigation depended significantly on moisture conditions over the period of high water needs of faba bean, spanning the growth stages from flowering to full reap (BBCH 60-89) that occur in the period June - July. In wet seasons, the increases in seed yields due to irrigation were insignificant and about three-fold lower, while in the dry periods - more than a half higher $(57 \%)$ than the average increases. The results presented in the work are of great importance because the formulas can be used to model forecasts of production and its economic effects, as well as to plan the development of irrigation systems in a given area.

\section{References}

1. Adamska, H., Gniadzik, M., Gołab, I., \& Kozak, M. (2016). Opłacalność uprawy wybranych roślin bobowatych (Production profitability of selected legumes). Roczniki Naukowe SERiA XVIII(4), 9-13. (in Polish).

2. Bąk, B., \& Łabędzki, L. (2002). Assessing drought severity with the relative precipitation index and the standardised precipitation index. Journal of Water and Land Development 6, 89-105.

3. Bryla, D., Banuelos, G., \& Mitchell, J. (2003). Water requirements of subsurface drip-irrigated faba bean in California. Irrigation Science 22, 31-37. DOI: 10.1007/s00271-003-0065-7.

4. Di Paolo, E., Garofalo, P., \& Rinaldi, M. (2015). Irrigation and nitrogen fertilization treatments on productive and qualitative traits of broad bean (Vicia faba var. minor L.) in a Mediterranean environment. Legume Research 38(2), 209-218. DOI: 10.5958/0976-0571.2015.00069.7.

5. Dudek, S., Żarski, J., \& Kuśmierek-Tomaszewska, R. (2011). Wpływ deszczowania na plonowanie bobiku uprawianego na glebie lekkiej (Effect of sprinkling irrigation on the yield of faba bean cultivated on light soil). Infrastruktura i Ekologia Terenów Wiejskich 6, 119-126. (in Polish).

6. Dudek, S., Kuśmierek-Tomaszewska, R., Żarski, J., \& Szterk, P. (2013). Ocena potrzeb i efektów deszczowania bobiku w warunkach zróżnicowanego nawożenia azotowego (Evaluation of requirements and effects of sprinkling faba bean under different nitrogen fertilization). Infrastruktura i Ekologia Terenów Wiejskich 1(II), 25-35. (in Polish).

7. Grabarczyk, S., \& Żarski, J. (1992). Próba statystycznej weryfikacji niektórych wzorów określających ewapotranspirację potencjalną (An attempt at statistical verification of selected formulae estimating potential evapotranspiration). Zeszyty Naukowe ATR w Bydgoszczy 180, 169-176. (in Polish).

8. Guide to Meteorological Instruments and Methods of Observation: (CIMO guide) (2014). WMO Publisher (edition updated in 2017). WMO-No. 8. Retrieved February 23, 2018, from: https://library.wmo.int/doc_ num.php?explnum_id=4147.

9. Guttman, N. (1999). Accepting the Standardized Precipitation Index: a calculation algorithm. Journal of the American Water Resources Association 35(2), 311-322. DOI: 10.1111/j.1752-1688.1999.tb03592.x.

10. Kuśmierek-Tomaszewska, R., Żarski, J., \& Dudek, S. (2012). Meteorological automated weather station data application for plant water requirements estimation. Computers and Electronics in Agriculture 88, 44-51. DOI: 10.1016/j.compag.2012.07.002. 
11. Łabędzki, L. (2007). Estimation of local drought frequency in central Poland using the standardized precipitation index SPI. Irrigation and Drainage 56, 67-77. DOI: 10.1002/ird.285.

12. Łabędzki, L. (2009). Przewidywane zmiany klimatyczne a rozwój nawodnień w Polsce (Predicted climate changes and irrigation development in Poland). Infrastruktura i Ekologia Terenów Wiejskich 3, 7-18. (in Polish).

13. Ouji, A., Naouari, M., Mouelhi, M., \& Ben Younes, M. (2017). Yield and Yield Components of Faba Bean (Vicia faba L.) as Influenced by Supplemental Irrigation under Semi-arid Region of Tunisia. World Journal of Agricultural Research 5(1) 52-57. DOI: 10.12691/wjar-5-1-7.

14. Podleśny, J. (2005). Rośliny strączkowe w Polsce - perspektywy uprawy i wykorzystanie nasion (Legumes in Poland - future prospects of cultivation and seeds utilization). Acta Agrophysica 6(1), 213-224. (in Polish).

15. Rokosz, E., \& Podsiadło, C. (2015). Wpływ deszczowania, system uprawy i nawożenia mineralnego na plonowanie i właściwości fizyczne gleby lekkiej w uprawie odmian bobiku (Influence of irrigation, tillage system and mineral fertilization on the yield and physical properties of light soil in the cultivation of variety of faba bean). Infrastructure and Ecology of Rural Areas III(1), 625-636. DOI: 10.14597/ infraeco.2015.3.1.050. (in Polish).

16. Rolbiecki, S., Rolbiecki, R., Rzekanowski, C., \& Żarski, J. (2000). The influence of sprinkler irrigation on yields of some vegetable crops in the region of Bydgoszcz, Poland. Acta Horticulturae 537, 871-877. DOI: 10.17660/ActaHortic.2000.537.105.

17. Rolbiecki, S., Rolbiecki, R., Kuśmierek-Tomaszewska, R., Dudek, S., Żarski, J., \& Rzekanowski, Cz. (2015). Requirements and effects of drip irrigation of mid-early potato on a very light soil in moderate climate. Fresenius Environmental Bulletin 24(11b), 3895-3902.

18. Rzekanowski, C., Żarski, J., \& Rolbiecki, S. (2011). Potrzeby, efekty i perspektywy nawadniania roślin na obszarach szczególnie deficytowych w wodę (Requirements, results and perspectives of plant irrigation on the areas characterized by distinct water deficits). Postępy Nauk Rolniczych 1, 51-63. (in Polish).

19. Sarkar, S., Sarkar, A., \& Zaman, A. (2017). Effect of irrigation and phosphorus levels on broad bean (Vicia faba L.) for improving growth, yield and water extraction pattern. Legume Research 40 (2), 257-263. DOI: 10.18805/lr.v0i0.7587.

20. Szukała, J., Czekała, J., Maciejewski, T., \& Jakubus, M. (2007). Wpływ współdziałania uproszczeń uprawy roli, deszczowania i nawożenia na plonowanie i jakość nasion bobiku (Effect of reduced tillage, nitrogen fertilization and sprinkling interaction on yielding and seed quality of field bean). Zeszyty Problemowe Postępów Nauk Rolniczych 522, 351-360. (in Polish).

21. Święcicki, W., Chudy, M., \& Żuk-Gołaszewska, K. (2007). Rośliny strączkowe w projektach badawczych Unii Europejskiej (Grain legumes in the UE framework programmes). Zeszyty Problemowe Postępów Nauk Rolniczych 522, 55-65. (in Polish).

22. World reference base for soil resources 2014: International soil classification system for naming soils and creating legends for soil maps: update 2015. World Soil Resources Reports No.106. Retrieved June 29, 2018, from: http://www.fao.org/.

23. Wszelaczyńska, E., Pobereżny, J., Dudek, S., Kuśmierek-Tomaszewska, R., Żarski, J., \& Pawelzik, E. (2015). The effects of fertilizers, irrigation and storage on the properties of potato tubers and their constituent starches. Starch/Stärke 67, 478-492. DOI: 10.1002/star.201400196.

24. Żarski, J., Dudek, S., Kuśmierek-Tomaszewska, R., Rolbiecki, R., \& Rolbiecki, S. (2013). Prognozowanie efektów nawadniania roślin na podstawie wybranych wskaźników suszy meteorologicznej i rolniczej (Forecasting effects of plants irrigation based on selected meteorological and agricultural drought indices). Annual Set The Environment Protection 15, 2185-2203. (in Polish).

25. Żarski, J., Dudek, S., Kuśmierek-Tomaszewska, R., \& Żarski, W. (2017). Effects of agricultural droughts in the province of Kujawsko-Pomorskie and possibilities of minimizing their impact. Infrastructure and Ecology of Rural Areas II(2), 813-824. DOI: 10.14597/infraeco.2017.2.2.063. 